\title{
Drought Adaptation and Coping Strategies among Coffee Farmers in the Central Highlands of Vietnam
}

\author{
Phuong Le Nguyen', Mau Dung Nguyen²
}

\author{
${ }^{1}$ Vietnam National University of Agriculture, lehanoi2005@yahoo.com \\ 2 Vietnam National University of Agriculture, maudung@vnua.edu.vn \\ Correspondence: lehanoi2005@yahoo.com or nguyenphuongle@vnua.edu.vn. Tel: (84) 397592248
}

\begin{abstract}
Vietnam is the second largest coffee producer in the world, mostly from the Central Highlands region where water has been becoming a scarce resource. Since 2014, drought has been strongly affecting Central Highlands' agriculture, particularly coffee production. The drought leads to changes in flowering, ripening and thus harvesting times of coffee. Coffee productivity has reduced about 50 percent. Ultimately, coffee quantity and quality is jeopardized which endangers coffee farmers who occupy 90 per cent of population and their livelihoods mainly rely on coffee. Most of coffee farmers have had to develop alternative strategies to respond to the drought. Based on quantitative and qualitative data collected from 50 coffee households in a community in the Central Highlands, this research has indicated that farmers had to find the ways to adapt as well as to cope with drought. The ways of adaptation and coping were diverse, including short, medium and longterm plans. To strengthen the adaptation and coping strategies of farmers with drought in the short term, it is recommended that authorities provide more technical and financial support to farmers. Furthermore, longer term strategies need to focus on land use planning, investment in irrigation schemes, and consolidated afforestation schemes in appropriate areas.
\end{abstract}

Keywords: Drought; Coffee farmers; Adaptation; Coping strategies; Central Highlands

\section{Introduction}

According to several scholars, "drought is a natural but temporary imbalance of water availability, consisting of a persistent lower-than-average precipitation, of uncertain frequency, duration and severity, of unpredictable or difficult to predict occurrence, resulting in diminished water resources availability, and reduced carrying capacity of the ecosystems. Many other definitions of drought exist" (Yevjevich, 1967; Dracup et al., 1980; Wilhite and Glantz, 1987; Tate and Gustard, 2000). Generally, these definitions clearly state that drought is mainly due to the breakdown of the rainfall regime, which causes a series of consequences, including agricultural and hydrological hazards that result from the severity and duration of the lack of rainfall. "The less predictable characteristics of droughts with respect to their initiation and termination, frequency, and severity make drought both a hazard and a disaster: a hazard because it is a natural event of unpredictable occurrence but of recognizable recurrence; a disaster because it causes the disruption of the water supply to the natural and agricultural ecosystems as well as to other human activities" (Ana and Pereira, 2006).

Drought is a recurring climatic phenomenon that is caused by the deficiency of precipitation over a certain period of time, leading to a water shortage for human activities and environment (Sivakumar et al., 2010). Drought is not simply dry condition characterized by low precipitation and high evapotranspiration. It would be defined as a moisture condition that is below the normal condition or lower than expectation (Wilhite and Glantz, 1985). Drought is also different from floods, storms, and earthquakes because it is long duration event and difficult to identify (Wilhite, 2010).

Drought events are normally characterized by drought indices (Liu et al., 2016). However, the disagreement among the definitions of drought makes it difficult to develop a universal drought index (Heim, 2002). As a consequence, hundreds of indices have been introduced. According to the World Meteorological Organization (Hounam et al. 1975), "droughts are classified as either 
meteorological (lack of precipitation over a region for a period of time), hydrological (a period with inadequate surface and subsurface water resources), agricultural (a period with declining soil moisture and consequent crop failure due to lack of surface water resources), or socioeconomic (failure of water resources systems to meet demands, which impacts human activities both directly and indirectly)". In this study, drought is considered from on socioeconomic aspect. Particularly, drought is defined as an imbalance between the supply and demand of water for coffee production, however, it does not use the quantitative methods of existing studies. Instead, drought is looked from the perception of coffee growers.

With climate change, "the frequency and magnitudes of droughts are very likely to increase and the poor nations are very vulnerable to such changes" (IPCC, 2014). The climate change in Vietnam "is strongly affected by monsoons and its complex topography. The total precipitation amount in the dry season accounts for approximately $15-25 \%$ of the annual precipitation. According to a drought assessment by the Ministry of Agriculture and Rural Development (MARD), Vietnam, in 1997-1998, about three million people were affected and the total losses in terms of agricultural production were estimated to be about 400 million US dollars" (Vu et al., 2013; Dao, 2002). It could be said that the El Niño event in 1997-1998 was extremely strong and had severe impacts on the environmental and socio-economic sectors of Vietnam. In addition, Nguyen and Rosbjerg (2007) found that "the effects of El Niño in the South are often stronger than in the North of Vietnam. The Central Highlands is one of the most sensitive regions to El Niño effect, which often leads to serious drought during the dry season".

'The drought episode in 2003 reduced coffee production by about $25 \%$. Domestic water supplies were also threatened. Since 2014, the drought associated with the El Niño phenomenon has been strongly affecting Vietnam again. A recent report has shown at least one-third of Vietnam's 63 provinces continue to be affected by El Niño-induced drought, which resulted in crop damage, yield decline and serious water shortage. Eighteen provinces in the South Central, Central Highlands and Mekong Delta regions have been severely affected. As a result of the drought in 2015-2016, the discharges of main rivers have been reduced by 20-90\% (NCHMF, 2016). By early April 2016, water volumes in most of the irrigation reservoirs in the Central Highlands declined to $10-50 \%$ of their designed capacity" (CGIAR, 2016).

About $70 \%$ of cultivation areas in the Central Highland, which are rain-fed or covered by small irrigation systems, have experienced severe drought (MARD, 2016). "Up to mid-April, nearly 170,000 ha of crops were affected by the drought, of which 7,100 ha were left fallow and more than 95,000 ha were deficient in irrigation. In Dak Lak province, reduction of crop production was estimated for more than 42,400 ha and is equivalent to nearly USD 60 million. Lack of feeds (grasses and forage) and water has also affected the livestock production in the Central Highlands. According to the Department of Agriculture and Rural Development (DARD) in Dak Lak, more than 100 heads of cattle have died by mid-April due to the drought. Ea Rve and Ia Lop communes of Ea Sup district, particularly, have lost 109 heads of cattle and hundreds of poultry" (CGIAR, 2016).

Among a variety of crops, drought causes the main impacts in the coffee sector. Optimal conditions to produce Robusta coffee include temperatures between 22 and $26^{\circ} \mathrm{C}$ and annual rainfall around 1,500ml. For Arabica coffee temperatures between 15 and $24^{\circ} \mathrm{C}$ and 1,500 to 2,000ml of rainfall per year are ideal. Coffee plants are fairly vulnerable to even small changes in climatic conditions. The drought leads to changes in flowering, ripening and thus harvesting times; strong winds cause reduced flowering and the falling of coffee flowers and cherries; and changes in temperatures lead to more frequent or new pest and disease attacks (Henriette et al., 2016). Ultimately, coffee quantity and quality is jeopardized which endangers coffee producers who occupy 90 per cent of population and their livelihoods mostly rely on coffee.

In response to the impacts of the drought on coffee production, adaptation and coping practices are therefore necessary to reduce vulnerability as well as to prepare for possible future extreme climate events. Adaptation theory is often attributed to change among human populations and natural ecosystems, and its conceptualization is instrumental as a practice, process, activity, 
program, or evaluation. The Intergovernmental Panel on Climate Change reports (IPCC 2001, 2007, 2012) define adaptation as an adjustment in natural or human systems in response to actual or expected climatic stimuli or their effects, which moderates harm or exploits beneficial opportunities. Adaptation therefore involves adjustments in reducing the vulnerability of households to climatic variability and change (Adger et al. 2007). For more clearly, adaptation can be thought of as a response, a design, an activity, or a feature in order to manifest and improve recovery and resilience (Conway and Mustelin, 2014; Jones et al., 2010; Sedjo, 2010).

In the economic literature, two types of adaptation with regard to the relevant actors are distinguished: (i) autonomous adaptation, motivated by the private, utility-maximizing paradigm of firms and individuals, and (ii) planned adaptation, based on collective action and mostly initiated by governmental entities. Autonomous adaptation occurs as individuals naturally respond to the market and physical environment or other circumstances they face. It can also be described as a behavioral response to an environmental change that is mainly for one's own benefit (Mendelsohn, 2000). Planned adaptation on the other hand is the result of a strategic policy decision for the sustainable benefit of a society. In this paper, the autonomous adaptation of private households who grow coffee in the context of drought and how to strengthen autonomous adaptation strategies by supplying information and providing supports from the public sector.

Familiarity with adaptation as a coping strategy has yet to be more assimilated into the public's current understanding and knowledge about climate change issues. Blaikie et al. (1994) define coping as the manner in which people act within existing resources and ranges of expectation in a given context to achieve various ends. Therefore, adaptation involves longer-term shifts in livelihood strategies, while coping involves temporary adjustment in response to change or to mitigate shocks and stresses on livelihoods (Eriksen et al. 2005; Migosi et al. 2012). However, adaptation or coping mechanisms of people to different hazards in general and to drought in particular vary from household to household based on their "coping capacity" or "adaptive capacity".

The terms "coping capacity" and "adaptive capacity" generally include both used and unused capacities. Coping capacity is defined by UNISDR (2009) as "... the ability of people, organizations and systems, using available skills and resources, to face and manage adverse conditions, emergencies or disasters ..." which can "... contribute to the reduction of disaster risks." While the term "adaptive capacity" is the ability of a system to adjust to climate change (including climate variability and extremes) to moderate potential damages, to take advantage of opportunities or to cope with the consequences" (IPCC, 2007). The adaptive capacity is different across and within societies. This could stem from differences in resource endowment, perception of risk, farmers' experience and knowledge (Adger et al., 2007).

The adaptation and coping strategies of coffee producers to the drought have been studied for decades (Fábio M. and José D., 2006; Zuluaga et. al, 2015; Henriette et. al, 2016; Jennifer FinleyLezcano et. al, 2016; Mugagga, 2017; Läderach et. al, 2017). The literature showed that coffee productivity and quality is highly dependent on temperature and rainfall conditions (Haggar and Schepp, 2012), and is relatively sensitive to drought, excessive moisture, and wind damage (Tucker et al., 2010). The blossoming and fructification of coffee, in particular, requires a specific series of dry and rainy seasonal alternation (Haggar and Schepp, 2012). Thus, unpredictable rains will cause coffee to flower at various times throughout the year leading to continuous harvesting of small quantities of coffee (Fábio M. and José D., 2006; Mugagga, 2017). At the same time, researches have shown that coffee growers have knowledge and skills that enable them to adapt to and cope with the climate change in general and the drought in particular (Jennifer Finley-Lezcano et. al, 2016; Mugagga, 2017; Fábio M. and José D., 2006; Läderach et. al, 2017; Zuluaga et. al, 2015). Jennifer Finley-Lezcano et. al (2016) pointed out that in order to adapt to climate change, coffee growers in Latin America have developed strategies such as: income diversification, solar dryers, seed banks and nurseries, pest monitoring and management, and water collection systems.

Smallholder coffee farmers have been responding to the climate variability through a range of 
interventions including shifting planting dates, planting additional crops and crop varieties, changing the mix of crops on the same plot, investing in fruit crops etc. (Mugagga, 2014; Masiga, 2012; Ngigi, 2009). Adding shade in the coffee systems is an adaptation strategy that can reduce temperatures in the coffee canopy by up to $2^{\circ} \mathrm{C}$ and shade trees or crops such as bananas also provide short-term benefits like additional food and income (Jassogne, et. al, 2013). Based on two adaptation strategies to two levels of climate change (incremental adaptation for lower levels of progressive climate change and transformative adaptation for higher levels of progressive climate change), Läderach et. al (2017) has developed a two-dimensional adaptation framework in time and space for coffee production in Nicaragua. According to these authors, the incremental adaptation occurs in a short timeframe at lower altitudes, whereas the same areas may undergo transformative adaptation in the long term. At higher altitudes incremental adaption may be needed in the long term. The same principle and framework is applicable across coffee growing regions around the world, as the patterns of decreasing exposure with higher altitudes are the same globally; only the magnitude and timeframe changes.

This study examines drought situation and how drought impacted on coffee production; identifies adaptation processes more broadly as long-term strategies and analyzes temporary coping responses to drought of coffee growers in the Central Highland, Vietnam. Knowledge and skill of coffee growers' adaptation and coping responses to drought stresses can guide possible intervention measures, as well as better policy implications for strengthening the individual adaptive strategies.

\section{Methodology}

Study site selection

The Central Highlands is one of eight agro-ecological regions of Vietnam. The region consists of various plateaus surrounded by mountain ranges. The elevations of plateaus range from 500-1500 masl (meters above sea level). The Central Highlands has a total land area of 5,454,500 ha (17\% of the national area), covering five provinces: Kon Tum, Gia Lai, Dak Lak, Dak Nong and Lam Dong. Among the five Central Highlands provinces, Dak Lak has the largest coffee area (200,000 ha) and produces over $40 \%$ of the total production in Vietnam. Cu M'gar district has around 36,000 hectares of land under coffee cultivation and is one of largest coffee producers of the 15 districts of Dak Lak. Moreover, Cu M'gar is considered as one of the districts which has been facing the most severe drought problems in the province due to reduced rainfall and uneven water allocation at various times of the year. In the dry season, all crops including coffee are faced with water shortages, while flooding may occur in rainy season. In consultation with the district government, two communities representing different ethnic groups in $\mathrm{Cu}$ Sue commune, $\mathrm{Cu} \mathrm{M}^{\prime}$ gar district were selected to investigate the strategies that farmers use to cope with the drought for coffee production. The Sut H'Luot, Sut M'DRang and Sut M'Dung villages were selected to interview the Ede (an ethic community) coffee farmers, whereas the Village \# 1 and Village \# 2 were chosen to interview the Kinh (majority group) coffee growers.

\section{Data collection}

Both primary and secondary data was collected for this study in two year 2015 and 2016. The primary data was collected through directly interviewing fifty coffee farmers in the selected villages. Farmers were selected on the basis of acquiring data from a range of scales of coffee production and levels of diversification in terms of livelihood strategies. For production scale, based on the consultation of village headmen and local statistical classification, three scales have been selected including large (over one hectare/household), medium (from 0.5 to one hectare/household) and small (less than 0.5 hectare). Regarding to livelihood diversification, households were classified based on how many income generation activities what they have conducted. Questionnaires were developed as a guideline for semi-structured interviews including basic information about the householders at each farm and the strategies farmers have applied in order to adapt to and to cope with the drought. Three focus group discussions were also held with the participation of local government staff and famers to 
identify the most appropriate strategies in adaptation and coping with the drought in the region. Participant observation was also used to gather information in each community.

\section{Data analysis}

First, descriptive statistics were used to characterize the drought situation in each region including the loss of coffee productivity and the formulation and implementation of adaptive and coping strategies for responding to the drought in coffee production. Secondly, comparative analyses were used to understand how different adaptive and coping strategies have been selected by different farm household groups (Ede and Kinh).

\section{Results and Discussion}

\subsection{The Drought and Water shortage in Coffee Production}

$\mathrm{Cu}$ Sue commune in $\mathrm{Cu} \mathrm{M}^{\prime}$ gar district has undergone tremendous economic and social change since Vietnam's reunification in 1975 after Vietnam-US war. Previously, the main economic activities of the community where the Ede minority group are predominant were subsistence production of rice using swidden-cultivation, supplemented by hunting, fishing and gathering. Ede people also cultivated secondary crops in gardens and raised animals. Mutual assistance and reciprocity was widespread (Dang, 2003). After 1975, Vietnam's communist government launched a major resettlement campaign in New Economic Zones (NEZs) to better utilize labor, diversify the economy, accelerate collectivization, and ensure the security of peripheral regions.

The government simultaneously implemented its Fixed Cultivation and Sedentarization Program (FCSP) to motivate ethnic minorities to abandon rotational shifting cultivation and other normadic practices. Collective ownership of land was instituted at the village-level and traditional tribal lands were declared state property, eligible for redistribution. Villagers were encouraged to participate in cooperatives, state farms and forestry enterprises. Throughout the Central Highlands, NEZs brought different types of people together, particularly from the Central Coast and Red river delta. Between 1976 and 1980, nearly half a million people were resettled in NEZs in the three provinces of the Central Highlands, and another 260,000 were resettled between 1981 and 1988 (Muller, 2004). By 1985 there were twenty-five NEZs in Dak Lak province (Fortunel, 2000). All members of the Ede minority in $\mathrm{Cu}$ Sue lived on rice shifting cultivation until the establishment of the State-run Ea Pok Coffee Company in 1985. Since that time, Ede farmers in the three studied villages were required to use fixed cultivation practices. All Ede farmers in the area were allocated about two thousand square meters of residential land and one hectare of state land with which to grow coffee. After Doi Moi, with liberalizing economic policies, fertile soil and an ideal local climate, both the Ede and Kinh farmers in $\mathrm{Cu}$ Sue commune achieved yields of up to five tons of coffee bean per hectare, and buoyant coffee prices throughout the 1990s provided high cash incomes.

The rise of the Vietnamese coffee economy nearly doubled that of the Vietnamese Gross Domestic Product in Dak Lak province, particularly in Cu M'gar district within a decade. However, the rapid agricultural transformation of the province has raised a number of environmental concerns. Many observers have noted that coffee production in the region has tended to follow an extensive, rather than an intensive practice. Total land used for agricultural production in Dak Lak doubled in the 1990s, with an average increase of 46,000 hectares per year. People said that coffee cultivation in Vietnam goes hand-in-hand with deforestation, land degradation and depletion of water resource. Indeed, between 1980 and 2000, Dak Lak province lost forest at an average rate of 20,000 hectares per year (ADB 2003). Forest destruction in $\mathrm{Cu}$ Sue can now be seen as a cause by which surface water can no longer be stored in the forests and groundwater reserves deepen.

Surface water is mostly sourced from small streams. Although there are many small streams in the district with density of 0.6 to $0.7 \mathrm{~km} / \mathrm{km} 2$, they are unevenly allocated. It was witnessed that there were very few streams flowing through $\mathrm{Cu}$ Sue commune. One hundred percent of the Ede respondents indicated that the streams could not help them in the years 2015 and 2016 because there was not any water. 
According to statistical data, rainfall in $\mathrm{Cu}$ Sue has not significantly fluctuated from year to year. The coefficient of variation was very small (from 0.1 to 0.2 ). However, in 2016 the rainfall was observed to dramatically decrease, and as a result the drought in the area became more severe than ever. Usually, the rainy season starts in March, but in 2016, the first rain in Cu Sue occurred in late June. The rainfall in the rainy season (from March to October) accounts for 87 percent of the total rainfall, especially for 93.5 percent in 2015. Thus, there is a big conflict between water demand for coffee production (high demand for coffee watering in the dry) and water availability in the region.

Table 1. Rainfall and Evaporation in Dak Lak

\begin{tabular}{|c|c|c|c|}
\hline Month & Rainfall (mm) & Evaporation $\mathbf{( m m )}$ & Deficit (mm) \\
\hline 1 & 13 & 95 & -82 \\
\hline 2 & 7 & 98 & -91 \\
\hline 3 & 7 & 122 & -115 \\
\hline 4 & 77 & 128 & -51 \\
\hline 5 & 151 & 140 & 11 \\
\hline 6 & 155 & 137 & 18 \\
\hline 7 & 184 & 140 & 44 \\
\hline 8 & 145 & 137 & 8 \\
\hline 9 & 220 & 120 & 100 \\
\hline 10 & 205 & 106 & 99 \\
\hline 11 & 199 & 91 & 108 \\
\hline 12 & 62 & 88 & -26 \\
\hline
\end{tabular}

Source: Bui Duc Ha, 2015

The difference between the demand and availability of water for coffee production would be manageable based on the development of an effective irrigation scheme which has not been invested enough in this area. Currently in $\mathrm{Cu}$ Sue commune, there are two water reservoirs which have designed capacities to irrigate 120 hectares of coffee (out of 2500 hectares in total) and 60 hectares of rice (out of 160 hectares in total). In practice, these reservoirs are capable of irrigating only 60 hectares of coffee, focusing on only two of the eleven villages of the commune. However, there is not any drain to transport the water from the reservoirs to the Ede villages where the research has been conducted. Moreover, there is not any solution for water harvest implemented in the region. In the Kinh villages, there are some small rice and coffee areas that can be watered thanks to a canal which was invested in by an international project in order to drain water from Buon Yong reservoir to the commune.

It seemed the Kinh villages can more easily access to water sources than Ede's ones. The main reason is the fact that after Doi Moi, both indigenous and migrant households were eligible for land use rights embodied in so called "red books". In a situation where land became commoditized they lacked the concept of individual land ownership, being accustomed to the communal land ownership with periodic reallocation of land by clan elders in their traditional system of shifting cultivation. To make things worse, the coffee price fell steeply from January 1999, bankrupting many of the poorest and least skilled farmers. Indigenous households were often lured or forced to sell off their lands to newcomers or to rich farmers (UNHCR, 2002). As a result, indigenous households including Ede have been repelled in the remote areas.

Reports in local newspapers showed a drought crisis of increasing severity and the water scarcity problem in the Central Highlands region and in $\mathrm{Cu} \mathrm{M}^{\prime}$ gar district in particular has been widely publicized. Both local and central governments are concerned with the declining volume of water in reservoirs, rivers, and streams. Coffee growers in $\mathrm{Cu}$ Sue commune reported that they have been suffering from water shortages since 2015. In 2016, the water scarcity has become so serious that majority of the paddy fields in the commune were unirrigated. All respondents referred to a peak drought occurring in April and May 2016 when villagers could not obtain water from usual sources 
for domestic use. In Sut M'Dung village, dozens of families might purchase freshwater contained in plastic tanks for domestic uses which restricted to drinking and cooking purposes.

For coffee production, almost all farmers in the region have irrigated by groundwater reserved from individual wells. Survey data showed that each coffee plantation needs one or two wells depending on its size. The average depth of the wells is 26.8 meters and one well can service an area of approximately 6,400 square meters. Since 2015, many households have deepened their wells, with some households even digging extra wells to seek water for saving their coffee plantations. The high density of more deepened household wells have caused severe ground water degradation. The groundwater has been lower about seven meters if we compare level in 2014 with 2010 in Cu M'gar district (Department of Agriculture and Rural Development, personal communication, 2015).

Local farmer's watering practice is one of the reasons that caused water scarcity in the Central Highland. A common practice is that water is pumped up to the plantation and applied by means of a hose. Based on local knowledge, about three doses of $70 \mathrm{~mm}$ (650 liters/tree) are required for mature trees under optimal planting conditions (1111 trees/ha spaced $3.0 \mathrm{~m} \times 3.0 \mathrm{~m}$ ) (Luu, 2002; Bau, 1984). By field observations and interviews with local people, D'Haeze (1999) indicated sub-optimal planting densities with an average of 1005 trees/ha which results in the excavation of larger planting holes around individual bushes. Local coffee farmers mentioned that these are completely replenished with water, making that farmers use an estimated average of 900 liters/tree per application. This may be explained by the fact that farmers expect a virtually unlimited linear increase of coffee production in function of the applied water dose and through recognition of the fact that water is not considered an economic input (water has no price). In contrast with the locally advised doses and farmers' irrigation management, D'Haeze et al. (2003) demonstrated at WASI that an application of 390 liters/tree suffices during flower set of the coffee bushes. As a consequence present farmers' irrigation management results in a factor 2.3 over-irrigation (D'Haeze et al., 2005). In this study, the survey data shows that farmers use 600 liters/tree per application (about 1.5 times overirrigation). If there is sufficient water, coffee is irrigated between four and five times per year as outlined in the Table 2.

Table 2. Watering Schedule for Coffee

\begin{tabular}{|l|c|c|}
\hline Purpose of Watering & Duration & Irrigation Events \\
\hline Flower blooming & $\begin{array}{l}\text { From the second January to } \\
\text { the early February }\end{array}$ & $1-2$ \\
\hline \multirow{2}{*}{ Seed fostering } & March & 1 \\
\cline { 2 - 3 } Before harvesting & April & 1 \\
\hline Total & September & 1 \\
\hline
\end{tabular}

Source: Interviewed data, 2016

In brief, the drought in Central Highland can be seen as the consequence of the El Nino that makes the region getting drier whereas the over expansion of coffee plantation and the overuse of water for coffee irrigation caused the degradation of ground water level. Further, the lack of irrigation scheme is a factor which makes water shortage in coffee production.

\subsection{Influences of Drought on Coffee Production as Perceived by Farmers}

The impacts of drought on agricultural sector in general and on coffee production in particular have been studied by several researchers (D’Haezea et. al, 2005; Fábio M. and José D., 2006; Opiyo et. al, 2015). Drought wreaks havoc on coffee flowering. If it doesn't rain at the right time, or if it rains too much or too little, flowering is uneven at best and meager at worst. Drought produces smaller beans of uneven size and lighter density. Beans of varying size grades are bad for specialty coffee roasters who need more uniformity to get an even roast. Smaller beans affect both quantity and quality of coffee, then influence farmers' income from coffee. 
According to local coffee growers, the first irrigation application (from the second half of January onwards every 20-25 days till the end of dry season) is the most important because it strongly impacts upon coffee productivity. However, as mentioned in previous section, the most crucial need for water by coffee trees is the dry season to keep trees alive. In 2015 and 2016, the villagers experienced drought and they could not maintain the watering schedule for coffee. Almost all respondents supposed that their coffee plantations experienced water scarcity. The times of coffee irrigation have been dramatically changed. The interviewed data showed that during the drought, farmers had to irrigate their coffee almost 7 times per year. Furthermore, the duration of an irrigation application increased from 3.5 days per time before 2015 to 21 days per time in 2016. For example, a respondent who had a plantation with 340 coffee trees stated that she could irrigate only 10 trees per day because her well has been lacking in water for over a year (A female coffee farmer, personal communication). Like many households in the village, she could not determine the time spending on irrigation or the duration of an irrigation event as she needed to prioritize the daily irrigation of some trees while letting over other coffee trees die.

\section{Impoverishment due to Water Scarcity}

A female farmer and her family have lived in Sut H'Luot village since 1985 when the fixed cultivation policy was implemented. She and her husband have to work to feed three children. Both of them are literate. They have been given two plantations with total 10,000 square meters and a rice field with 300 square meters by their parents. Before 2014, they could harvest coffee on all areas. Annually, her family could earn 2,500 kg of coffee bean. But since 2014, water has become scarce, so one of their plantations of 5,000 square meters could not be irrigated. Coffee trees in the non-irrigated plantation have all died, while the other plantation has experienced water shortages since early 2016. In 2015, $300 \mathrm{~kg}$ of coffee bean, $200 \mathrm{~kg}$ of paddy, and $50 \mathrm{~kg}$ of maize were harvested. The female farmer and her husband have been working as hired-farm labors 5 days a month which they have rarely done before. The per capita of the family was about 400,000 VND per annum, equivalent to poverty line announced by Ministry of Labour, Invalids and Social Affairs.

According to People's Committee annual report, $\mathrm{Cu}$ Sue commune has 2400 hectares of coffee. In 2015, 293 hectares had no harvest while 442 hectares had a reduced productivity by between 30 to 70 percent. This represents an equivalent reduction in household income from coffee. The coffee productivity of surveyed households reduced from 2.6 tons per ha in 2010 to 1.4 tons per ha in 2015 . One villager reported only harvest $200 \mathrm{~kg}$ of coffee per hectare in 2015 (A female farmer in Sut H'Lout village, personal communication). On further discussions in April and June of 2016, she predicted that her family may not harvest any coffee seed in that year. Strongly impacted by drought, all coffee producers in $\mathrm{Cu}$ Sue had to develop their coping and adapting strategies.

\subsection{Coffee Growers' Adaptation and Coping Strategies to Drought}

This research focuses on coping strategies and adaptation of household farms rather than on government intervention. On the basis of the ways in which farmers practice coffee production as well as the coping strategies farmers selected to save their livelihoods in response to the drought for coffee production.

\subsubsection{Coping Strategies of Coffee Farmers}

Coffee farmers in $\mathrm{Cu}$ Sue applied various coping responses against the drought events. As discussed in previous section, coping strategies are more reactive and mainly involve temporary adjustment of livelihood activities in response to drought. Among the 16 households who decided to dig more wells, ten could not find any water and this coping strategy had to be discontinued after digging ten or even twenty meters in depth. Many household chose the coping strategy of deepening their existent wells. However, the financial investment associated with the well deepening was expensive and only 36 percent of the survey households could afford this. Four households were able to share 
water with their siblings and neighbors, however all of these respondents were Kinh people who lived closed to a water source. As having no water, all Ede households could not employ water sharing techniques. Five other households had adopted the coping strategy of buying water from their neighbors at price of $30,000 \mathrm{VND}$ per hour of pumping.

The most popular short-term strategy was found to be changing the watering schedule. Majority of respondents reported this approach. Prior to the drought, one farmer could irrigate one thousand coffee trees per day, but since 2015, each well was found to be depleted of water after irrigating only twenty or thirty coffee trees. Thus, farmers needed to divide their plantation and irrigate rotationally. By doing that, they could water about a hundred coffee trees per day. As a consequence, farmers had to devote more time and to spend more money for diesel and electricity. Most of respondents could not calculate how their family labor spending on coffee watering increased, but they confirmed that the diesel cost was triple.

Table 3. Short-term Coping Strategies with Drought for Coffee Production

\begin{tabular}{|l|c|c|c|c|c|}
\hline \multicolumn{1}{|c|}{ Individual Strategies } & \multicolumn{2}{|c|}{$\begin{array}{c}\text { Households applying } \\
\text { strategies }\end{array}$} & \multicolumn{2}{c|}{$\begin{array}{c}\text { Duration of strategy } \\
\text { application (percent) }\end{array}$} \\
\cline { 2 - 6 } & $\begin{array}{c}\text { Number } \\
(\mathrm{n}=50)\end{array}$ & Percent & $\begin{array}{c}\text { Before } \\
\text { drough } \\
\mathrm{t}\end{array}$ & $\begin{array}{c}\text { During } \\
\text { drought }\end{array}$ & $\begin{array}{c}\text { After } \\
\text { drought }\end{array}$ \\
\hline 1. Digging more wells & 16 & 32.0 & 12.5 & 62.5 & 25.0 \\
\hline 2. Deepening wells & 18 & 36.0 & 11.1 & 72.2 & 16.7 \\
\hline 3. Sharing water & 4 & 8.0 & 0 & 100.0 & 0 \\
\hline 4. Purchasing water & 5 & 10.0 & 0 & 100.0 & 0 \\
\hline 5. Changing schedule of watering & 50 & 100.0 & 10.0 & 90.0 & 0 \\
\hline
\end{tabular}

Source: Interviewed data, 2016

The question is that why low proportion of respondents have applied the first coping strategy (digging well more). The respondents showed the reasons were the fact that they are lack of money (75 percent), lack of labor (12.5 percent) and no permission of local government (12.5 percent).

Further analysis showed that all coping strategies have been practiced by respondents mainly during drought period. Additionally, after the drought the strategies of digging more well and deepening well have been applied more often than before. This means that farmers have learnt how to cope with the drought from their perceived risk.

\subsubsection{Adaption Strategies of Coffee Farmers}

A majority of households in $\mathrm{Cu}$ Sue commune have developed several adaptation strategies to mitigate the adverse impacts of drought. Adaptation strategies are (1) intercropping practice, particularly growing pepper and avocados in the coffee plantations and to reduce the number of coffee trees in order to grow other crops such as maize and cassava; (2) Livelihood diversification including seeking jobs outside the village to work as industrial workers, as vendors in urban areas, and using the money to hire farm laborers; integrating the coffee crops with livestock raising; and (3) Practicing water saving techniques for coffee production. These strategies have been co-existed in some, but mostly separated by economic and social conditions of each households.

Table 4. Intercropping Practices as an Adaptation Strategy to Drought

\begin{tabular}{|c|c|c|c|}
\hline Individual Strategies & $\begin{array}{c}\text { Number } \\
(\mathrm{n}=50)\end{array}$ & Percent & $\begin{array}{c}\text { Beginning } \\
\text { time }\end{array}$ \\
\hline
\end{tabular}




\begin{tabular}{|l|c|c|c|}
\hline 1. Intercropping culture & & & \\
\hline - Pepper intercropped with coffee & 50 & 100.0 & 2012 \\
\hline - Avocado intercropped with coffee & 15 & 30.0 & 2014 \\
\hline - Pepper and avocado intercropped with coffee & 15 & 30.0 & 2014 \\
\hline 2. Cut down coffee to grow maize and cassava & 5 & 10.0 & 2015 \\
\hline
\end{tabular}

Source: Interviewed data, 2016

Intercropping culture is the most popular adaptation strategy which has been applied by coffee farmers by 100 percent of respondents. All households had decided to intercrop with pepper in their coffee plantation. As the price of pepper has been high for four years, farmers in $\mathrm{Cu}$ Sue have intercropped with pepper since 2012 at different scales. Some households have grown 500 pepper trees together with 500 coffee trees while the others kept 800 coffee with 200 pepper trees per hectare depending on the coffee productivity. Avocado has been also grown since 2014. According to respondents, avocado is easily sold at reasonable price, but seedlings are so expensive that few households can afford to invest in this strategy. Economic efficiency of intercropping models is witnessed in the Table 5. Some households whose coffee plantation cannot access to water decided to replace coffee trees with annual crops such as maize and cassava. These households planned to return to coffee production when water situation improves.

Table 5. Economic Efficiency of Intercropping Models

Unit: Million VND/ ha/year

\begin{tabular}{|l|c|c|}
\hline \multicolumn{1}{|c|}{ Cropping patterns } & Mixed Income & Ranking \\
\hline 1. Intercropping & & \\
\hline - Pepper intercropped with coffee & 154.39 & High \\
\hline - Avocado intercropped with coffee & 244.76 & High \\
\hline - Durian and avocado intercropped with coffee & 160.09 & High \\
\hline 2. Monoculture & & Medium \\
\hline - Coffee & 90.00 & \\
\hline
\end{tabular}

Source: WASI, 2017

According to the data in the Table 5, the applications of intercropping of pepper and fruit trees with coffee such as avocado and durian brought high economic efficiency, but model of avocado with coffee produced the highest mixed income (the income includes family labor cost) and the most stable due to the high market demand, less labor, and reasonable price. Moreover, soil quality in $\mathrm{Cu}$ Sue commune is very relevant to avocado cultivation. The model of intercropping durian and avocado with coffee has higher profit than that of the monoculture and of pepper with coffee. However, the model of intercropping durian and coffee has ecological advantages such as: (i) Durian can shade and protect coffee from wind so that it reduces evaporation of coffee leaves in dry season; (ii) Durian's leaf canopy is so sparse that there is enough light for coffee; and (iii) Farmers can apply similar fertilizer and pesticide for both coffee and durian.

Together with intercropping culture, diversification of local livelihood is a major strategy practiced by all respondents. In this research livelihood diversification has been considered as a process by which households constructed their diverse portfolio of income generating activities. Under the context of drought, there is an appearance of new livelihood strategies such as working as street vendors and industrial workers and developing animal husbandry livelihoods, particularly goats.

Table 6. Livelihood diversification activities of surveyed households

\begin{tabular}{|c|c|c|c|}
\hline \multicolumn{1}{|c|}{ Individual Strategies } & Number & Percent & $\begin{array}{c}\text { Income per year } \\
\text { (Million VND) }\end{array}$ \\
\hline Seeking jobs outside the village (person) & 28 & & \\
\hline
\end{tabular}




\begin{tabular}{|l|c|c|c|}
\hline - As industrial workers & 05 & 17.86 & 24,000 \\
\hline - As farm-hired labors & 18 & 64.28 & 7,200 \\
\hline - As vendors in urban area & 05 & 17.86 & 21,000 \\
\hline Investing in Livestock (household) & 35 & & \\
\hline - Goat & 05 & 14.29 & 6,000 \\
\hline - Pig & 10 & 28.57 & 12,000 \\
\hline - Chicken & 15 & 42.85 & 4,000 \\
\hline - Chicken and pig & 05 & 14.29 & 11,000 \\
\hline
\end{tabular}

Source: Interviewed data, 2016

The data in Table 6 indicates that although all households have been engaging in livelihood diversification strategies, most of them still depend on climate sensitive activities such as livestock raising and farm casual labor. Mobility is a popular risk reduction strategy, particularly in times of drought employed by farmers in different regions (Francis Opiyo et al., 2015; Mohieldeen, 1999). Seeking jobs outside community is also diverse among households in the Central Highlands. Kinh people were found to be more active in coping with water shortage situation, especially in regards to seeking outside jobs outside the village. Kinh families have paid much more attention to the education of their children than Ede and Dzao. As a result, their adult daughters and sons are able to find jobs as industrial workers in Ho Chi Minh City, Binh Duong and Dong Nai provinces. Furthermore, those who do not want to migrate to other provinces have the capacity to generate income from other activities such as vending in Buon Me Thuot city which is 15 kilometers away from $\mathrm{Cu}$ Sue commune or working as industrial workers in the Tan An industrial zone which is located approximately 8 kilometers from the commune. On the contrary, almost all Ede people in $\mathrm{Cu}$ Sue are dependent on coffee farming or working as casual hired farm labors surrounding the village. A key cause of this is that they are not qualified for industrial jobs.

The in-depth interview results compared well with the literature (Ngan, 2009) that found that language constraints are one of the major factors limiting young people from migrating from the village as a coping strategy. Although majority of young Ede people can speak and understand Vietnamese, they often do not carry out the instructions of managers correctly, thus, young Ede peoples from Sut H'Luot and Sut M'Drang villages who tried to go to work in the Tan An industrial zone decided were found to return home after just seven months of working.

Together with seeking off-farm jobs, developing animal husbandry has been considered as a coping strategy in response to severe drought. Five out of fifty survey households have recognized that goats can be fed not only by grass, but also by acacia leaves. Acacia has been grown in coffee plantations to stand as trestles of pepper trees, and to provide feed for goats. Moreover, acacia also provides good conditions for coffee trees, providing the shady forest conditions that they prefer and fixing nitrogen (fertilizer) for their growth. A respondent believed that raising goats could be a suitable livelihood strategy for both Kinh and Ede people in the context of water scarcity because of feed availability and high demand for goat meat. However, as this economic activity is still new villagers still worry about the feed source and technical requirements.

Aside from diversification of livelihood strategies, application of water saving technique in coffee production was considered as a long-term adaptation strategy to drought. However, only two households in the study areas have been applying this technique. Both of them were Kinh people who migrated from the Red river delta in the early 1990s. The reasons are the fact that: (i) First, this technique requires a high financial investment. Farmers need to invest about one hundred million VND for an Israel-designed drip-irrigation system and about 40 million VND for a Vietnamesedesigned one that can cover two hectares of coffee plantation (Cam Lai, 2015 and Tam Nhin, 2014), whereas the average size of a coffee plantation is only 0.6 hectares. (ii) Thus, the scale of the coffee plantation is the second reason the application of drip-irrigation is limited. (iii) Third, if farmers apply drip irrigation, the fertigation is required through drip irrigation tubes. If fertilizers purchased are not of high quality then they will not dissolve and cause maintenance issues with the pipes. Fourth, 
sabotage and theft of irrigation equipment in the village is another reason that constrain investment in drip irrigation as a water saving methodology.

\subsection{Strengthening Farmers' Adaptation and Coping Strategies}

Several adaptation and coping strategies that employed by coffee growers have been analyzed in previous sections. Nevertheless, it is not sure that how many villagers in this area can and need to adopt the strategies in future. Moreover, they can adopt in which condition. Information in the Table 7 shows that each adaptation and coping strategy not only brought benefits, but also caused un-intended consequences differently to particular persons (women or men). Besides, in order to be successful, those who apply the particular strategies need special capacities and supports.

Table 7: Assessing the Coping Strategies in the Context of Water Scarcity

\begin{tabular}{|c|c|c|c|c|}
\hline $\begin{array}{l}\text { Possible coping } \\
\text { strategies }\end{array}$ & $\begin{array}{l}\text { Who benefits } \\
\text { from this } \\
\text { option? }\end{array}$ & $\begin{array}{c}\text { Capacities needed } \\
\text { to carry out this } \\
\text { option? }\end{array}$ & $\begin{array}{l}\text { What supports } \\
\text { are necessary? }\end{array}$ & $\begin{array}{l}\text { Un-intended } \\
\text { consequences }\end{array}$ \\
\hline $\begin{array}{l}\text { Seeking water } \\
\text { sources (well } \\
\text { deepening or } \\
\text { digging, water } \\
\text { purchasing and } \\
\text { sharing...) }\end{array}$ & $\begin{array}{l}\text { Coffee } \\
\text { growers } \\
\text { (both women } \\
\text { and men) }\end{array}$ & $\begin{array}{l}\text { - Households that } \\
\text { have enough } \\
\text { financial resource } \\
\text { - Men are mainly } \\
\text { responsible for } \\
\text { seeking water } \\
\text { sources }\end{array}$ & $\begin{array}{l}\text { Financial } \\
\text { support from } \\
\text { government or } \\
\text { development } \\
\text { programs }\end{array}$ & $\begin{array}{l}\text { - Water resource } \\
\text { degradation } \\
\text { - Financial and health } \\
\text { burden } \\
\text { - Female family members } \\
\text { and children are negatively } \\
\text { impacted because } \\
\text { households have to devote } \\
\text { financial and human } \\
\text { resources for seeking } \\
\text { water. }\end{array}$ \\
\hline $\begin{array}{l}\text { Changing } \\
\text { watering } \\
\text { schedule }\end{array}$ & $\begin{array}{l}\text { Coffee } \\
\text { growers } \\
\text { (both women } \\
\text { and men) }\end{array}$ & $\begin{array}{l}\text { Households have } \\
\text { enough family } \\
\text { labor or those who } \\
\text { can hire outside } \\
\text { labors }\end{array}$ & $\begin{array}{l}\text { Training from } \\
\text { agricultural } \\
\text { extension } \\
\text { officers }\end{array}$ & $\begin{array}{l}\text { Farmers, particularly } \\
\text { women have suffered from } \\
\text { workload as they have to } \\
\text { devote more time to } \\
\text { watering than ever }\end{array}$ \\
\hline $\begin{array}{l}\text { Intercropping } \\
\text { patterns }\end{array}$ & $\begin{array}{l}\text { Coffee } \\
\text { growers } \\
\text { (both women } \\
\text { and men) } \\
\text { Community }\end{array}$ & $\begin{array}{l}\text { Households that } \\
\text { have enough both } \\
\text { financial and } \\
\text { human resources }\end{array}$ & $\begin{array}{l}\text { Training from } \\
\text { agricultural } \\
\text { extension } \\
\text { officers }\end{array}$ & $\begin{array}{l}\text { - Over-production of } \\
\text { pepper and avocado may } \\
\text { happen, so farmers may } \\
\text { face with no market for sell } \\
\text { - Women have to work } \\
\text { harder as they must take } \\
\text { care of several crops at the } \\
\text { same time }\end{array}$ \\
\hline $\begin{array}{l}\text { Water saving } \\
\text { technique } \\
\text { application } \\
\text { (dripping } \\
\text { irrigation } \\
\text { system) }\end{array}$ & $\begin{array}{l}\text { Coffee } \\
\text { growers } \\
\text { (both women } \\
\text { and men) } \\
\text { Community }\end{array}$ & $\begin{array}{l}\text { - Households that } \\
\text { have enough } \\
\text { financial resource. } \\
\text { - Fertilizers and } \\
\text { pesticides need to } \\
\text { be high quality } \\
\text { enough in order to } \\
\text { be dissolved in the } \\
\text { tube. }\end{array}$ & $\begin{array}{l}\text { Financial and } \\
\text { technical } \\
\text { support from } \\
\text { government or } \\
\text { other } \\
\text { development } \\
\text { programs }\end{array}$ & $\begin{array}{l}\text { - Sabotage and theft of } \\
\text { irrigation equipment in } \\
\text { the village } \\
\text { - Women may be lagged } \\
\text { behind if they cannot } \\
\text { operate watering system }\end{array}$ \\
\hline $\begin{array}{l}\text { Livelihood } \\
\text { diversification }\end{array}$ & $\begin{array}{l}\text { Coffee } \\
\text { growers } \\
\text { Community }\end{array}$ & $\begin{array}{l}\text { Labors have } \\
\text { professional, } \\
\text { language, and }\end{array}$ & Local initiative & $\begin{array}{l}\text { Local people, especially } \\
\text { women might face with } \\
\text { social risks from outside }\end{array}$ \\
\hline
\end{tabular}




\begin{tabular}{|l|l|l|l|l|}
\hline $\begin{array}{c}\text { Possible coping } \\
\text { strategies }\end{array}$ & $\begin{array}{l}\text { Who benefits } \\
\text { from this } \\
\text { option? }\end{array}$ & $\begin{array}{c}\text { Capacities needed } \\
\text { to carry out this } \\
\text { option? }\end{array}$ & $\begin{array}{l}\text { What supports } \\
\text { are necessary? }\end{array}$ & $\begin{array}{c}\text { Un-intended } \\
\text { consequences }\end{array}$ \\
\hline $\begin{array}{l}\text { (women, } \\
\text { men, girls } \\
\text { and boys) }\end{array}$ & integrated skills. & & \\
\hline programs & $\begin{array}{l}\text { Coffee } \\
\text { growers } \\
\text { Community } \\
\text { (women, } \\
\text { men, girls } \\
\text { and boys) }\end{array}$ & $\begin{array}{l}\text { Implementing } \\
\text { relevant } \\
\text { government } \\
\text { programs }\end{array}$ & $\begin{array}{l}\text { Financial and } \\
\text { technical } \\
\text { supports from } \\
\text { government } \\
\text { programs }\end{array}$ & $\begin{array}{l}\text { - Irrelevant } \\
\text { implementation of } \\
\text { government programs }\end{array}$ \\
\hline
\end{tabular}

Source: Research Team's Synthesis

Based on the needs of supports and un-intended consequences shown in Table 7, policy recommendations have been drawn for strengthening farmers' adaptation and coping strategies as below:

\section{Short-term Recommendations}

First, local governments, particularly line departments such as the District office of Agriculture and Rural Development, Agricultural Extension Agencies, and DoNRE should provide technical guidelines and financial support for collecting rainwater during the wet season, particularly in small reservoirs or dams at the household scale.

Second, provincial and district line departments need provide early warnings and recommendations for farmers in the context of water scarcity. Together with warning provision, suggestions for appropriate crops for each season and crop varieties should be given.

Third, water scarce situations, technical irrigation guidelines for coffee plantations should be available both in order both to save crops and to ensure productivity, and this needs to be need to be communicated quickly to farmers.

\section{Medium-term Recommendations}

First, local governments should support adaptation strategies, especially for intercropping patterns. Currently, strategies used for intercropping have selected trees varieties based on market prices and popular local systems include pepper and avocado. All farmers have spontaneously intercropped in coffee plantations without official guidelines. Technical assistance from local governments may help farmers determine which crops can be integrated with coffee and financial support to facilitate this adoption could be provided.

Second, as water scarcity has affected coffee production, some households have developed livestock raising strategies, especially for raising goats and pigs. Pigs can be fed mainly by agricultural by-products and food wastes, while goats are raised by wild grasses and acacia leaves from pepper trellises. In order to promote such livelihood strategies, local authorities need to provide improved agricultural extension services, low interest credit, relevant breeding stocks, and links to output markets. The integrated crop-livestock system of coffee, acacia, pepper and goat may prove to be an appropriate productive model in the context of water shortages in $\mathrm{Cu}$ Sue commune.

\section{Long-term Recommendations}

First, after the Doi Moi economic reforms, government policies towards liberalization have encouraged coffee production, but existing property rights to land and weak enforcement have led to an over-expansion of areas under coffee cultivation. This in turn has resulted in a high demand for groundwater. Since groundwater is largely an open access resource and no explicit rules for its use are in operation, individuals exploit groundwater resources at a cost to the community. Coffee cultivation also includes other negative externalities like soil erosion, deforestation and water depletion that transcend beyond the commune boundaries. Land use planning strategies that determine a sustainable cultivation area for coffee production are required to avoid a high density of coffee plantations, and associated irrigation wells should be implemented by the Dak Lak provincial 
government.

Secondly, according to FAO AQUASTAT (2014), Vietnamese agricultural production consumes large amounts of fresh surface water with 95 percent of primary surface water being used for agriculture and livestock. Between1996 to 2006, irrigated areas increased by 50 percent, however, these irrigation schemes prioritized rice production. It can be observed that 80 percent of irrigated areas are prepared for rice, whereas maize, rubber, and coffee cultivation comprise of three percent of irrigated areas. This situation is reflected in $\mathrm{Cu} \mathrm{M}$ 'gar district where irrigation schemes have inadequate investment and are mostly concentrated in rice cultivation areas. Irrigation infrastructure such as dams, reservoirs and canals should focus on a broader range of crops, including industrial crops like coffee.

Thirdly, small plantation sizes constrained the use of water saving technology such as drip irrigation systems for coffee production. Therefore, ongoing initiatives to consolidate fragmented land holdings should be further fostered and encouraged. In addition, low interest credit for water efficient irrigation application should be provided.

Finally, local governments also need to focus on afforestation, especially in the upper reaches of rivers and other strategic areas, for improved adaptation strategies to respond to natural disasters, such as drought in the long-term.

\section{Concluding remarks}

Drought in $\mathrm{Cu}$ Sue commune, Dak Lak province has become increasingly severe due to a range of factors including a reduction of rainfall, lowering of the groundwater table, poorly planned irrigation schemes, high density industrial crop plantations, and deforestation. Water scarcity has resulted in a decline in coffee productivity, and then in producers income. Some households who have been strongly dependent on coffee production have fallen into poverty. In response to this situation, central and provincial governments have promoted and implemented a number of solutions, in particularly coping strategies in short-term in order to mitigate these impacts. However, it was assessed that the government interventions have been not effective in addressing the problems. As a result, farmers have developed their own strategies to cope with water scarcity for coffee production and their livelihoods.

Although short-term coping strategies differed from household to household, they were mainly associated with digging more wells, deepening wells, purchasing water, sharing water, and changes to irrigation schedule. The most popular adaptation strategy was intercropped cultivation, integrating of coffee plantations with pepper, avocadoes, durian and acacia. Then, livelihood diversification and application of water efficient irrigation methods were the second popular strategies.

Policy recommendations for supporting farmer coping strategies have been drawn from field research and focused on: (1) technical and financial assistance to farmers in the short and medium term; and (2) institutional changes to land use planning, irrigation scheme investment, land consolidation and afforestation for the long-term.

Acknowledgements: I am grateful to acknowledge funding from the project of CGIAR Research Program on Water, Land, and Ecosystems (WLE) and Australian Aids hosted by Mekong Sub-region Social Research Center (MSSRC), Faculty of Liberal Arts, Ubon Ratchathani University, Thailand (MK32). Special thanks to hundreds of people in five villages of my study site who shared their knowledge and helped me to finish my research.

Author Contributions: Data curation has been done by Dr. Mau Dung Nguyen and Dr. Phuong Le Nguyen wrote the draft manuscript.

\section{REFERENCES}

1. Adger, W.N., Agrawala, S, Mirza, M., Monirul, Conde C., O’Brien, K., Pulhin, J., Pulwarty, R., Smit, B., Takahashi, K (2007) Assessment of Adaptation Practices, Options, Constraints and Capacity. In: M.L Parry, O.F. Canziani, J.P. Palutikof, P.J. van der Linden and C.E. Hanson (eds.) Climate Change 2007: 
Impacts, Adaptation and Vulnerability. Contribution of Working Group II to the Fourth Assessment Report of the Intergovernmental Panel on Climate Change. Cambridge University Press. Cambridge: UK, pp.717-743.

2. Ana A. Paulo and Luis S. Pereira (2006). Drought Concepts and Characterization: Comparing Drought Indices Applied at Local and Regional Scales. Water International. International Water Resources Association. 31 (1).

3. Bau, L.N (1984) General research results on irrigation application depths in combination with mulching for Robusta coffee. In: Annual Report. Western Highlands Agro-forestry, Science and Technical Institute, Dak Lak, Vietnam, pp. 162-190.

4. Blaikie, P., Cannon, T., Davis, I., and Wisner, B (1994) At Risk: Natural Hazards, Peoples Vulnerability and Disasters. Routledge: London.

5. Cam Lai (2015). Hiệu quả từ việc ứng dụng công nghệ tưới nhỏ giọt Israel điều tiết nở hoa cà phê (Efficiency of Israel water saving techniques in coffee flowering). Agricultural News. http://www.tintucnongnghiep.com/2015/03/hieu-qua-tu-viec-ung-dung-cong-nghe.html.

6. CGIAR (Research Centers in Southeast Asia) (2016) The Drought Crisis in the Central Highlands of Vietnam: Assessment Report. CGIAR Research Program on Climate Change, Agriculture and Food SecuritySoutheast Asia

7. Conway, D., and Mustelin, J (2014) Strategies for improving adaptation practice in developing countries. Nature Climate Change. 4(5): 339- 342.

8. D. D’haeze, J. Deckers, D. Raes, T.A. Phong and H.V. Loi (2005) Environmental and Socio-Economic Impacts of Institutional Reforms on the Agricultural Sector of Vietnam Land Suitability Assessment for Robusta Coffee in the Dak Gan Region. Agriculture, Ecosystems and Environment. 105 (2005):59-76.

9. D'haeze, D., Deckers, J., Raes, D., Phong, T.A., Chanh, N.D.M (2003) Over-irrigation of Coffea canephora in the Central Highlands of Vietnam revisited Simulation of soil moisture dynamics in Rhodic Ferralsols. Agric. Water Manag. 63 (3):185-202.

10. Dang, D.T (2003) Coffee Production, Social Stratification and Poverty in a Vietnamese Central Highland Community. In: R. DeKonick, J. Lamarre, and B. Gendron (eds) Understanding Poverty in Vietnam and the Philippines: Concepts and Context. Localized Poverty Reduction in Vietnam (LPRV) Project, pp. 71-100.

11. Dao, X.H (2002) Drought and Its Mitigation Measures. Hanoi: Agricultural Publishing House.

12. Dracup J.A., K.S. Lee, and E.D. Paulson (1980) On the Definition of Droughts. Water Resources Research.16 (2): 297-302.

13. Eriksen, S.H., Brown, K. and Kelly, P.M (2005) The dynamics of vulnerability: locating coping strategies in Kenya and Tanzania. The Geographical Journal. 171(4): 287 - 305.

14. Fábio M. DaMatta and José D. Cochicho Ramalho (2006) Impacts Of Drought And Temperature Stress On Coffee Physiology And Production: A Review. Brazilian Journal of Plant Physiol: 18(1):55-81.

15. FAO AQUASTAT. 2014. http://www.fao.org/nr/water/aquastat/data/query/index.html?lang=en

16. Fortunel, F (2000) Le Cafe' au Vie`tnam: de la Colonisation a`l'Essor d'un Grand Producteur Mondial. Paris: L'Harmattan.

17. Haggar, J. and Schepp, K (2012) Coffee and Climate Change: Impacts and Options for Adaptation in Brazil, Guatemala, Tanzania and Vietnam. Climate Change, Agriculture and Natural Resources. Working Paper Series No. 4. Natural Resources Institute. University of Greenwich: London http://www.academia.edu/2050482/Coffee_and_Climate_Change_Impacts_and_Options_for_Adaptatio n_in_Brazil_Guatemala_Tanzania_and_Vietnam

18. Heim, R (2002) A review of twentieth-century drought indices used in the United States. Bulletin of the American Meteorological Society. 83(8): 1149-1165.

19. Henriette Walz, Thiet Nguyen van, Henk van Rikxoort (2016) Climate Change and Vietnamese Coffee Production: Manual on Climate Change Adaptation and Mitigation in the Coffee Sector for Local Trainers and Coffee Farmers. Coffee Climate Care (C3).

20. Hounam, C.E., Burgos, J.J., Kalik, M.S., Palmer, W.C., and Rodda, J (1975) Drought and Agriculture. Technical Note 38. World Meteorological Organization. Geneva.

21. IPCC (Intergovernmental Panel on Climate Change) (2001) Climate change 2001: Impacts, adaptation and vulnerability. Contribution of Working Group II to the third assessment report of the IPCC. Cambridge: Cambridge University Press.

22. IPCC (Intergovernmental Panel on Climate Change) (2007) Climate change 2007: Impacts, adaptation and 
vulnerability. Contribution of Working Group II to the fourth assessment report of the Intergovernmental panel on climate change. Cambridge: Cambridge University Press.

23. IPCC (Intergovernmental Panel on Climate Change) (2012) Managing the risks of extreme events and disasters to advance climate change adaptation. A special report of Working Groups I and II of the Intergovernmental Panel on Climate Change. Cambridge: Cambridge University Press.

24. IPCC (Intergovernmental Panel on Climate Change) (2014) Climate Change 2014: Synthesis Report. Contribution of Working Groups I, II and III to the Fifth Assessment Report of the Intergovernmental Panel on Climate Change. Geneva, Switzerland. Retrieved from https://www.ipcc.ch/pdf/assessmentreport/ar5/syr/AR5 SYR FINAL SPM.pdf

25. Jassogne, L., Laderach, P., and Van Asten, P (2013) The Impact of Climate Change on Coffee in Uganda: Lessons from a case study in the Rwenzori Mountains. Oxfam Research Reports.

26. Jennifer Finley-Lezcano, Danielle King, Tianyu Wang (2016) Adaptation to Climate Change by Smallholder Coffee Producers in Latin America. Masters Project: Counter Culture Coffee. Nicholas School of the Environment. Duke University.

27. Jones Lindsey, Eva Ludi and Simon Levine (2010) Towards a characterisation of adaptive capacity: a framework for analysing adaptive capacity at the local level. ODI Background Notes. www.odi.org.uk/50years.

28. Läderach Peter, Julian Ramirez-Villegas, Carlos Navarro-Racines, Carlos Zelaya1, Armando MartinezValle, Andy Jarvis (2017) Climate Change Adaptation of Coffee Production in Space and Time. Climatic Change. 141:47-62.

29. Lui, X. F., Zhu, X. F., Pan, Y. z., Li, S. S., Liu, Y. X., and Ma, Y. Q (2016) Agricultural drought monitoring: Progress, challenges, and prospects. Journal of Geographical Sciences. 26(6), 750-767.

30. Luu, N., (2002) Exploitation capacity and recurrent groundwater resources in Dak Lak province ("kha nhang khai thac va hien trang tai nguyen nuoc duoi dat tinh Dak Lak"). Report, Institute of Meteorology and Hydrology, Buon Ma Thuot, Dak Lak, Vietnam.

31. MARD (Ministry of Agriculture and Rural Development) (2016) Steering committee of the action plan on climate change adaptation in agriculture and rural development. URL: http://occa.mard.gov.vn/. Accessed date: 15 Aug 2016.

32. Masiga, M (2012) Policy Brief: Adaptation and Mitigation Options, Territorial Approaches to Climate Change Project for Mbale Region, Uganda. https://adaptationundp.org/sites/default/files/downloads/tacc mbale cc adaptation and mitigation options policy brief final.pdf. Accessed date: 25 Sep 2017.

33. Mendelsohn, R (2000) Efficient Adaptation to Climate Change. Climatic Change 45. No. 3-4: 583-600.

34. Migosi, J., D. Nanok, C. Ombuki, and J. Metet (2012) Trends in primary school dropout and completion rates in the pastoralist Turkana County, Kenya. Universal Journal of Education and General Studies. 1(10): 331-338.

35. Mohieldeen, Yasir (1999) Responses to Water Scarcity: Social Adaptive Capacity and the Role of Environmental Information. A Case Study from Taiz, Yemen. Occasional Paper No. 23. Water Issues Study Group School of Oriental and African Studies (SOAS).

36. Mugagga Frank (2017) Perceptions and Response Actions of Smallholder Coffee Farmers to Climate Variability in Montane Ecosystems. Environment and Ecology Research 5(5): 357-366.

37. NCHMF (The National Center for Hydro-Meteorological Forecasting) (2016) Long term hydrological prediction of rivers in the Central coastal, Central Highlands and Mekong River Delta. URL: http://www.nchmf.gov.vn/web/vi-VN/71/65/28315/Default.aspx. Accessed date: 31 March 2016.

38. Ngan, H.T (2009) “Labor Remigration of Khmer Migrant Workers to Rural Areas in Vietnam: A Case Study in O Lam Village, Tri Ton District, An Giang Province". Individual Research funded by RDViet Project.

39. Ngigi, S.N (2009) Climate Change Adaptation Strategies: Water Resources Management Options for Smallholder Farming Systems in Sub-Saharan Africa. The MDG Centre for East and Southern Africa, The Earth Institute at Columbia University: New York.

40. Nguyen, T. D. and Rosbjerg, D (2007) Coping with drought in the central highlands - Vietnam. PhD Thesis, Institute of Environment and Resources, Technical University of Denmark.

41. Opiyo Francis, Oliver Wasonga, Moses Nyangito, Janpeter Schilling, Richard Munang (2015) Drought 
Adaptation and Coping Strategies Among the Turkana Pastoralists of Northern Kenya. International Journal of Disaster Risk Sci. (6):295-309. DOI 10.1007/s13753-015-0063-4. www.springer.com/13753.

42. Sedjo, Roger A (2010) Adaptation of forests to climate change. Development and Climate Change Discussion Paper No.3. Washington, DC: World Bank.

http://documents.worldbank.org/curated/en/744791468182041180/Adaptation-of-forests-to-climatechange.

43. Sivakumar, M., Motha, R., Wilhite, D., and Wood, D (2010) Agricultural Drought Indices: Summary and Recommendations. In: Agricultural Drought Indices Proceedings of an Expert Meeting, Murcia, Spain, 2-4 June 2010, pp. 172-197. Geneva, Switzerland: World Meteorological Organization.

44. Tucker Catherine M., Hallie Eakin, Edwin J. Castellanos (2010) Perceptions of risk and adaptation: Coffee producers, market shocks, and extreme weather in Central America and Mexico. ACT Publication No. 10-06. Anthropological Center for Training and Research on Global Environmental Change Indiana University, Student Building 331, 701 E. Kirkwood Ave., 47405-7100, U.S.A.

45. UNISDR (2009) 2009 UNISDR Terminology on disaster risk reduction. https://toolkit.ineesite.org/resources/ineecms/uploads/1287/UNISDR 2009 UNISDR Terminology on d isaster risk reduction.pdf

46. Vogt J.V., and F. Somma (eds) (2000) Drought and Drought Mitigation in Europe. Dordrecht: Kluwer.

47. Vu, T.H., Ngo, D.T., Phan, V.T (2013) Evolution of meteorological drought characteristics in Vietnam during the 1961-2007 period. Theor. Appl. Climatol. Doi: 10.1007/s00704-013-1073-z.

48. Wilhite D.A., and M.H. Glantz (1987) Understanding the Drought Phenomenon: the Role of Definitions. In: D.A. Wilhite, W.E. Easterling, and D.A. Wood (eds) Planning for Drought. Boulder, CO: Westview Press, pp.11-27.

49. Wilhite, D (2010) Drought as a natural hazard: Concepts and Definitions. In: Wilhite Drought (ed) $A$ Global Assessment. London: Routledge, pp. 3-18.

50. Wilhite, D., and Glantz, M (1985) Understanding the drought phenomenon: The role of definitions. Water International. 10:111-120.

51. Yevjevich V (1967) An Objective Approach to Definitions and Investigations of Continental Hydrologic Drought. Hydrology Paper No. 23. Fort Collins, CO: Colorado State University.

52. Zuluaga,Victor, Ricardo Labarta, and Peter Läderach (2015) Adaptation to Climate Change: The case of Nicaraguan Coffee Sector. Selected paper prepared for presentation at the 2015 Agricultural and Applied Economics Association and Western Agricultural Economics Association Annual Meeting, San Francisco, CA, July 26-28. 